Article

\title{
Consumers' Preferences for and Perception of CSR Initiatives in the Wine Sector
}

\author{
Marcello Stanco (D) and Marco Lerro*D \\ Department of Law, Economics, Management and Quantitative Methods, University of Sannio, 82100 Benevento, \\ Italy; mstanco@unisannio.it \\ * Correspondence: mrlerro@unisannio.it
}

Received: 1 June 2020; Accepted: 24 June 2020; Published: 27 June 2020

\begin{abstract}
This study explores consumers' preferences for corporate social responsibility (CSR) initiatives implemented in the wine sector. Moreover, it investigates consumers' perception and price premium for four wine certifications related to corporate social responsibility (i.e., SQNPI Sustainable Quality; V.I.V.A. Sustainable Wine; Organic, and Equalitas-Sustainable Wine). Overall 251 regular Italian wine consumers participated in an online survey. Their preferences for 11 CSR initiatives implemented in the wine sector were assessed through a best-worst scaling analysis. The study findings show that the most important CSR initiatives for consumers are "health and food safety", "sustainable agricultural practices", and "air pollution". By contrast, those least important for consumers are "energy consumption", "sustainable packaging", and "fair trade". Consumers expressed a positive perception in terms of CSR performance for all the certifications investigated, while their price premium was higher for wine with Organic certification. The study offers several implications for wineries. Specifically, it suggests the CSR initiatives that wineries may implement to fully meet consumers' preferences.
\end{abstract}

Keywords: best-worst analysis; wine certification; corporate social responsibility; Italian consumers; willingness to pay; price premium

\section{Introduction}

The wine sector is one of the most important agri-food sectors in the EU and in Italy either in terms of revenue or employment [1-3]. The Italian agri-food sector, in fact, is largely represented by the wine supply chain, especially when considering the value of exports, which, in 2018, was up to 5.44 billion euros for the certified wines (i.e., PDO, PGI) [4]. Further, it plays a crucial role in shaping the Italian rural landscape, which is heavily outlined by the presence of vineyards [5]. The latter, through thematic food and wine routes (e.g., the wine roads), act as a strategic lever to promote tourism in rural areas [6,7].

Over the last decade the Italian wine sector has faced several challenges, mainly due to the high competition from countries as Chile, New Zealand, and South Africa that are appearing in the world wine scene and expanding their market share [8,9]. Changes in citizen-consumers' preferences and consumption habits towards wine is putting the sector under pressure too [8]. Furthermore, while in the new wine countries there is an increase either in terms of production or consumption, in the old world wine countries (i.e., Italy, France, Spain) there is a contrasting situation [9]. The per capita wine consumption, in fact, is reducing in favor of other alcoholic beverages [10-12]. Moreover, citizen-consumers are evolving their wine preferences, paying more attention to the social, ethical, and environmental dimensions of wine production [13-16]. The concept of product quality is changing accordingly, incorporating the social costs associated with the production [17]. 
To face these challenges and societal concerns, wineries are currently implementing a strategic approach in their business operations, namely corporate social responsibility (CSR) $[18,19]$. CSR can account for social, environmental, and ethical issues of citizen-consumers. Further, it increases companies' reputation, meeting the current market needs and strengthening consumers' loyalty [20-22]. Lastly, a flourishing research stream shows that socially responsible agri-food companies are able to secure a price premium for their products [23-26].

On the one hand CSR creates several benefits for companies; on the other hand, the structure of the Italian wine sector is mainly characterized by small and medium-sized enterprises (SMEs), often family-run and with limited size [27] and financial resources, and this induces wineries to focus on few CSR initiatives. These are mostly related to the environmental and social dimension of CSR and are often locally limited [18]. Acknowledging consumers' preferences for CSR initiatives would enable wineries to adapt their business strategies, focusing their efforts on those initiatives more appealing to consumers.

The literature on consumers' preference for CSR initiatives in the agri-food sector is somewhat recent $[21,28,29]$ and, in some cases, focused on specific agri-food value chains such as milk $[24,30,31]$, meat [32], and fish [33]. As for the wine sector, studies on consumer preferences only marginally investigated corporate social responsibility. Specifically, they focused on consumers' preferences for wine with sustainable attributes [11,34-38] or with social, ethical, and environmental certifications $[13,39,40]$. Indeed, the literature on sustainability in the wine sector has arisen only recently [41,42]. Further, it focused mainly on the environmental dimension of sustainability [43,44], mostly implementing the life cycle assessment methodology [45-47]. Other scholars, instead, analyzed the sustainability programs and the certification processes at an international level, highlighting their main characteristics to clearly identify similarities and differences to the practitioners $[41,48]$. To the best of our knowledge, there is a lack of studies exhaustively analyzing consumer preferences for CSR initiatives [39,49].

This study goes in this direction, extending the current literature on wine consumer preferences. Specifically, it aims to assess: (i) consumers' preferences for different CSR initiatives implemented in the wine sector; (ii) consumers' perception of wine certifications related to CSR; (iii) consumers' price premium for different wine certifications related to CSR.

The next section of the paper summarizes the questionnaire administered, the CSR initiatives and certifications investigated, as well as the methodology carried out in the study. The study findings are shown in the Results section, while they are fully discussed in the Discussion one. The paper ends outlining the study implications and limitations.

\section{Materials and Methods}

\subsection{Survey Methodology and Questionnaire}

A web-based structured questionnaire was administered to a convenient sample of Italian wine consumers. Participants interviewed had to be above the minimum legal age for drinking alcohol (i.e., 18 years in Italy) and consume wine at least once a month. Data gathering took approximately two months, from April to May 2020, by implementing a nonprobability sampling method. Participation in the study was facilitated adopting different platforms (e.g., email, WhatsApp, Facebook, LinkedIn). Further, respondents were not granted any monetary incentives. The questionnaire opened with a brief message introducing the general purpose of the study and explaining that it was fully anonymous. To detect potential issues due to the misinterpretation of the questions posed, a pilot test was carried out with a limited number of participants (i.e., 20). No changes were made to the questionnaire as result of the pilot test.

The questionnaire consisted of five sections, while its completion took, on average, 20 minutes. Specifically, the first section posed a set of five questions to detect consumers' consumption habits such as frequency of consumption, place of purchase, place of consumption, consumption occasion, 
and wine purchase by price point. The second section of the questionnaire detected consumers' preferences for several CSR initiatives implemented in the wine sector, namely energy consumption, water consumption, air pollution, support for the local community, attention to the employees, fair trade, waste management, sustainable agronomic practices, health and food safety, biodiversity, and sustainable packaging. The third section of the questionnaire uncovered consumers' perception of four wine certifications related to corporate social responsibility (i.e., SQNPI Sustainable Quality; V.I.V.A. Sustainable Wine; Organic; Equalitas-Sustainable Wine). The four wine certifications were introduced to participants with a brief description and their logo (Table 1).

Table 1. Certifications assessed in the survey and their descriptions.

\begin{tabular}{|c|c|c|}
\hline Certification & Logo & Description \\
\hline $\begin{array}{l}\text { SQNPI } \\
\text { Sustainable } \\
\text { Quality }\end{array}$ & & $\begin{array}{l}\text { This certification shows that the wine was } \\
\text { obtained from grapes treated with } \\
\text { integrated cultivation practices (e.g., } \\
\text { limitation in the use of chemicals on grapes). }\end{array}$ \\
\hline $\begin{array}{l}\text { V.I.V.A. } \\
\text { Sustainable } \\
\text { Wine }\end{array}$ & 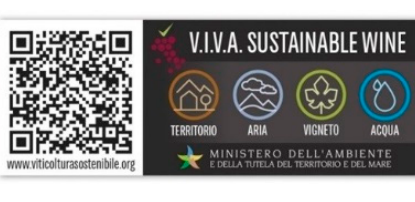 & $\begin{array}{l}\text { This certification shows that the winery } \\
\text { respects specific sustainability standards } \\
\text { both in vineyard and cellar. Sustainability is } \\
\text { assessed by four indicators: air, water, } \\
\text { vineyard, and territory. }\end{array}$ \\
\hline Organic & & $\begin{array}{l}\text { This certification shows that the wine is } \\
\text { organic and employs grapes obtained by } \\
\text { cultivation practices that ban the use of } \\
\text { pesticides or chemical fertilizers. Further, } \\
\text { the wine has a reduced sulfite content. }\end{array}$ \\
\hline $\begin{array}{l}\text { Equalitas- } \\
\text { Sustainable } \\
\text { Wine }\end{array}$ & 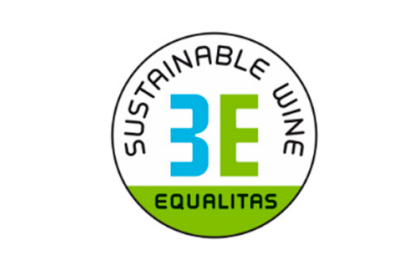 & $\begin{array}{l}\text { This certification shows that wine meets } \\
\text { specific sustainability standards and is } \\
\text { obtained adopting good agronomic and } \\
\text { cellar practices, as well as social } \\
\text { (relationships with local stakeholders) and } \\
\text { economic initiatives (employees' incentives } \\
\text { and fair prices for suppliers). }\end{array}$ \\
\hline
\end{tabular}

The fourth section of the questionnaire detected how much consumers are willing to pay more for each of the wine certifications explored in the study. Participants had to express how much they were willing to pay more (from $€ 0.00$ to $€ 3.00$ with 50 euro cent increments) for a $750 \mathrm{~mL}$ red wine bottle with the sustainable certification compared to one without it. Participants were informed that the average price for a $750 \mathrm{~mL}$ red wine bottle is $€ 5.00$.

In the fifth section of the questionnaire, respondents' socio-demographic characteristics were collected.

The following paragraphs describe, in detail, the methodology applied in the study to detect consumers' preferences for the 11 CSR initiatives, as well as their perception of the four wine certifications related to CSR.

\subsubsection{Consumers' Preferences for CSR Initiatives in the Wine Sector}

Consumers' preferences towards 11 CSR initiatives implemented in the wine sector were uncovered implementing a best-worst scaling (BWS) analysis [50]. The BWS analysis, also called maximum difference approach, was firstly implemented by Finn and Louviere [51] in the early 90s. Recently, several studies on consumer behavior [52-54], food preferences [55], and wine marketing [8,10,50,56] applied this methodology, mostly due to its main advantage. Compared to other evaluation methods, in fact, BWS analysis is free of bias related to respondent's culture. The method can rank consumers' 
preferences for specific attributes by asking consumers to pick the "best" and "worst" ones in terms of importance among different pairs of alternatives (i.e., the choice set). The latter are the characteristics that maximize the difference in utility.

The best-worst scaling analysis was introduced by a scenario describing the current issues that the wine sector is tackling. Then, a brief description of the 11 CSR initiatives assessed in the study was provided (Table 2).

Table 2. Corporate social responsibility (CSR) initiatives implemented in the wine sector.

\begin{tabular}{cl}
\hline $\begin{array}{c}\text { CSR Initiatives in the } \\
\text { Wine Sector }\end{array}$ & \multicolumn{1}{c}{ Description } \\
\hline Energy consumption & $\begin{array}{l}\text { The winery's involvement in reducing energy consumption in the vineyard and cellar } \\
\text { and/or to using energy produced from renewable sources. }\end{array}$ \\
\hline Water consumption & $\begin{array}{l}\text { The winery's involvement in reducing water consumption, also adopting a water recycling } \\
\text { system in cellar. }\end{array}$ \\
\hline Air pollution & $\begin{array}{l}\text { The winery's involvement in reducing the emissions generated by its activities and } \\
\text { consequently their impact on climate change. }\end{array}$ \\
\hline $\begin{array}{c}\text { Support for the local } \\
\text { community }\end{array}$ & $\begin{array}{l}\text { The winery's involvement in supporting donations to and/or sponsorships of local } \\
\text { initiatives (e.g., cultural, sports, etc.). }\end{array}$ \\
\hline employees & $\begin{array}{l}\text { The winery's involvement in giving all workers the same opportunities as well as fair or } \\
\text { higher than market wages. }\end{array}$ \\
\hline Fair trade & $\begin{array}{l}\text { The winery's involvement in supporting the economic development of the territory and } \\
\text { suppliers (e.g., ensuring a guaranteed minimum price). }\end{array}$ \\
\hline Waste management & $\begin{array}{l}\text { The winery's involvement in valorizing, internally, the byproducts produced (e.g., } \\
\text { fertilizers) and/or in other sectors (e.g., cosmetics, animal husbandry, energy, etc.). }\end{array}$ \\
\hline $\begin{array}{c}\text { Sustainable agronomic } \\
\text { practices }\end{array}$ & $\begin{array}{l}\text { The winery's involvement in adopting sustainable agronomic practices aimed at } \\
\text { preserving soil fertility and reducing the environmental impact. }\end{array}$ \\
\hline Health and food safety & $\begin{array}{l}\text { The winery's involvement in reducing the use of chemical products both in vineyard and } \\
\text { cellar (e.g., wines with reduced sulfite content). }\end{array}$ \\
\hline Biodiversity & $\begin{array}{l}\text { The winery's involvement in preserving biodiversity in the vineyard, promoting the } \\
\text { development of spontaneous flora and fauna. }\end{array}$ \\
\hline $\begin{array}{l}\text { The winery's involvement in adopting recyclable packaging and/or reducing } \\
\text { environmental impact such as corks made of glass or sugar cane and light glass bottles. }\end{array}$ \\
\hline
\end{tabular}

The current study implemented a balanced incomplete block design (BIBD) $(11,5,5,1)$ to assess the 11 CSR initiatives. Specifically, respondents were asked to repeatedly evaluate the CSR initiatives in 11 choice sets with five initiatives each repeated five times across the choice sets. As shown by Table 3 , in each choice set, respondents had to pick the "most" and "least" important CSR initiatives when purchasing a bottle of wine.

Table 3. Example of a choice set shown to participants.

Which of the Following Corporate Social Responsibility Initiatives do you Think are the Most Important and Least Important Aspects that a Winery Should Focus On?

\begin{tabular}{ccc}
\hline Most important & Weast important \\
$\square$ & Water consumption & $\square$ \\
$\square$ & Biodiversity & $\square$ \\
$\square$ & Waste management & $\square$ \\
$\square$ & Health and food security & $\square$ \\
$\square$ & Sustainable packaging & $\square$ \\
\hline
\end{tabular}

\subsubsection{Label Mapping}

In this section, participants had to state their perception of a $750 \mathrm{~mL}$ bottle of wine with different certifications related to CSR (i.e., SQNPI Sustainable Quality; V.I.V.A. Sustainable Wine; Organic; and Equalitas-Sustainable Wine). Specifically, they were asked to state how the four wine certifications 
perform in the 11 CSR initiatives investigated in the study. The CSR performance of the certified wines, compared to the ones without it, was assessed on a seven-point Likert scale where 1 is "much worse" and 7 is "much better".

The certifications explored in the study cover the main sustainable programs in the Italian wine market. Specifically, V.I.V.A. Sustainable Wine is an official certification provided by the Ministry for Environment, Land and Sea Protection that encompasses all three responsibilities of sustainability (i.e., environmental, social, and economic), while SQNPI Sustainable Quality ensures sustainability along the whole production process and was conceived by the Ministry of Agricultural, Food and Forestry Policies. Equalitas-Sustainable Wine is assessed considering environmental, social, and economic indicators that are verifiable and measurable. Lastly, Organic refers mainly to the environmental dimension of sustainability and is largely established among consumers.

\section{Results}

\subsection{Sample Description}

Overall, 266 participants took part at the study, while 251 respondents fully completed the questionnaire. Table 4 illustrates their descriptive statistics. The majority of participants were male (61\% of the total sample), in their forties (Mean age: $41 ; \pm 11.9$ ), and living in a family consisting, on average, of three members $( \pm 1.1)$. As for education, respondents tended to be highly educated, with roughly half of the sample holding a university degree $(48 \%)$ and a quarter either a high school degree $(24 \%)$ or a post-university degree (e.g., master's, PhD) $(24 \%)$. Lastly, the majority of respondents were employed (51.8\%) and had a monthly family income between $€ 2001$ and $€ 4000$ (39\%).

Table 4. Respondent demographics $(N=251)$.

\begin{tabular}{|c|c|c|c|c|c|}
\hline $\begin{array}{l}\text { Variable Name and } \\
\text { Description }\end{array}$ & Mean & Frequency & SD & Min & Max \\
\hline Gender & 0.390 & & $\mathrm{~N} / \mathrm{A}$ & 0 & 1 \\
\hline Female & & $39.0 \%$ & & & \\
\hline Male & & $61.0 \%$ & & & \\
\hline Respondent's age & 40.813 & & 11.962 & 18 & 75 \\
\hline Household size & 3.251 & & 1.175 & 1 & 8 \\
\hline \multicolumn{6}{|l|}{ Education level classes } \\
\hline Primary school & & $0.0 \%$ & & & \\
\hline Secondary school & & $3.2 \%$ & & & 5 \\
\hline High school & 3.936 & $24.3 \%$ & 0.782 & 1 & 5 \\
\hline University degree & & $48.2 \%$ & & & \\
\hline Above university degree & & $24.3 \%$ & & & \\
\hline \multicolumn{6}{|l|}{ Occupation status } \\
\hline Employed & & $51.8 \%$ & & & \\
\hline Self-employed & & $34.3 \%$ & & & \\
\hline Housewife/husband & 1.892 & $0.8 \%$ & 1.342 & 1 & 6 \\
\hline Retired & & $2.0 \%$ & & & \\
\hline Student & & $8.4 \%$ & & & \\
\hline Unemployed & & $2.7 \%$ & & & \\
\hline \multicolumn{6}{|l|}{ Family monthly income } \\
\hline classes & & $19.9 \%$ & & & \\
\hline$<€ 2000$ & & $38.7 \%$ & & & \\
\hline$€ 2001-€ 4000$ & 2.657 & $151 \%$ & 1.369 & 1 & 5 \\
\hline$€ 4001-€ 6000$ & & $\begin{array}{l}15.1 \% \\
8.4 \%\end{array}$ & & & \\
\hline$€ 6001-€ 8000$ & & $\begin{array}{r}8.4 \% \\
179 \%\end{array}$ & & & \\
\hline$>€ 8000$ & & $17.9 \%$ & & & \\
\hline
\end{tabular}




\subsection{Wine Consumption Habits}

Respondents stated that they drink wine regularly during the week (Table 5). Furthermore, the sample interviewed was roughly equally distributed among those drinking wine every day $(20 \%)$, 2-3 times per week (22\%), and once a week (20\%). The results show that respondents mostly prefer to purchase wine both at supermarkets, hypermarkets, discount stores (35\%), and directly from the producer $(33 \%)$. More than half of consumers interviewed drink wine at home $(56 \%)$ and during dinner (62\%). Finally, consumers spend, on average, between $€ 5.00$ and $€ 10.00(39 \%)$ on a $750 \mathrm{~mL}$ bottle of wine.

Table 5. Wine consumption habits of respondents.

\begin{tabular}{lc}
\hline \multicolumn{1}{c}{ Variable Name and Description } & Frequency \\
\hline Wine consumption frequency & \\
Every day & $20.3 \%$ \\
$4-5$ times per week & $7.6 \%$ \\
$2-3$ times per week & $22.3 \%$ \\
Once a week & $19.9 \%$ \\
2-3 times per month & $13.9 \%$ \\
Once a month & $16.0 \%$ \\
Favorite wine place of purchase & \\
Supermarket, hypermarket, discount store & $35.1 \%$ \\
Directly from the producer & $32.7 \%$ \\
Pub/restaurant & $9.2 \%$ \\
Wine bar & $13.5 \%$ \\
Online & $4.4 \%$ \\
Others & $5.1 \%$ \\
Favorite wine place of consumption & \\
At home & $55.8 \%$ \\
At friends' homes & $21.1 \%$ \\
Pub/restaurant & $18.3 \%$ \\
Lounge bar/wine bar & $4.8 \%$ \\
Favorite wine consumption occasion & \\
Lunch & $19.9 \%$ \\
Aperitif & $4.4 \%$ \\
Dinner & $62.2 \%$ \\
After dinner & $2.0 \%$ \\
Party & $10.8 \%$ \\
Others & $0.7 \%$ \\
Wine purchase by price point $€ 5.00$ & \\
between $€ 5.01-€ 10.00$ & $24.3 \%$ \\
between $€ 10.01-€ 15.00$ & $39.0 \%$ \\
between $€ 15.01-€ 20.00$ & $16.7 \%$ \\
between $€ 20.01-€ 25.00$ & $15.1 \%$ \\
$>€ 25.01$ & $3.2 \%$ \\
\hline & $1.7 \%$ \\
\hline
\end{tabular}

\subsection{CSR Preferences for Consumers}

To address the first study aim, a best-worst scaling analysis was implemented in the study. According to the study design, each CSR initiative was shown five times across the 11 choice sets. Thus, the individual best-worst score ( $\mathrm{B}-\mathrm{W}$ score) for the initiatives investigated ranges from +5 to -5 . Since the study design is balanced $[8,50]$, the $B-W$ scores generated through the difference of the frequencies are a fair approximation of those obtained by running a multinomial logit model [56].

Consumers' preferences for CSR initiatives are generated computing the individual B-W score (Table 6). This is calculated as the difference between the number of times a CSR initiative is picked as the most important from the times it is picked as the least important. Accordingly, a positive $B-W$ score implies an interest from consumers towards the CSR initiative. Indeed, a positive B-W score 
means that the number of times it is chosen as most important overcomes those where it is selected as least important. Conversely, when the B-W score is negative, consumers assign less value to a specific initiative. To this extent, consumers' purchasing behavior is not affected by that specific CSR initiative.

Table 6. Respondents' preferences for the CSR initiatives.

\begin{tabular}{lccc}
\hline \multicolumn{1}{c}{ CSR Initiatives } & Total Best & Total Worst & B-W Score \\
\hline Health and food safety & 710 & -44 & 666 \\
Sustainable agricultural practices & 449 & -112 & 337 \\
Air pollution & 284 & -123 & 161 \\
Waste management & 186 & -147 & 39 \\
Water consumption & 206 & -184 & 22 \\
Attention to the employees & 209 & -228 & -19 \\
Biodiversity & 152 & -182 & -30 \\
Support for the local community & 227 & -307 & -80 \\
Fair trade & 103 & -399 & -296 \\
Sustainable packaging & 102 & -422 & -320 \\
Energy consumption & 95 & -433 & -338 \\
\hline
\end{tabular}

The CSR initiatives are ranked according to the B-W score.

The results revealed that five out of 11 CSR initiatives were valued positively by consumers (Table 6). The CSR initiatives more important for respondents are "health and food safety" (B-W score: 666), "sustainable agricultural practices" (337), and "air pollution" (161). These CSR initiatives seem to have a positive and deep effect on consumers when purchasing a bottle of wine. By contrast, those least important for consumers are "energy consumption" (-338), "sustainable packaging" (-320), and "fair trade" (-296). These aspects are less likely to be taken into account by consumers in their purchasing decisions.

To assess if the B-W score means were statistically significant different, a paired-samples t-test was performed across all pairs of CSR initiatives (Table 7). Results show that a few pairs of CSR initiatives are not statistically significant (i.e., $p$-value higher than 0.05 ). Furthermore, the difference in the CSR initiatives is not equal to zero between "fair trade", "sustainable packaging", and "energy consumption"; among "waste management", "water consumption", "attention to the employees", and "biodiversity"; as well as between "attention to the employees", "biodiversity", and "support for the local community".

Table 7. Mean comparison of the CSR initiatives in the wine sector.

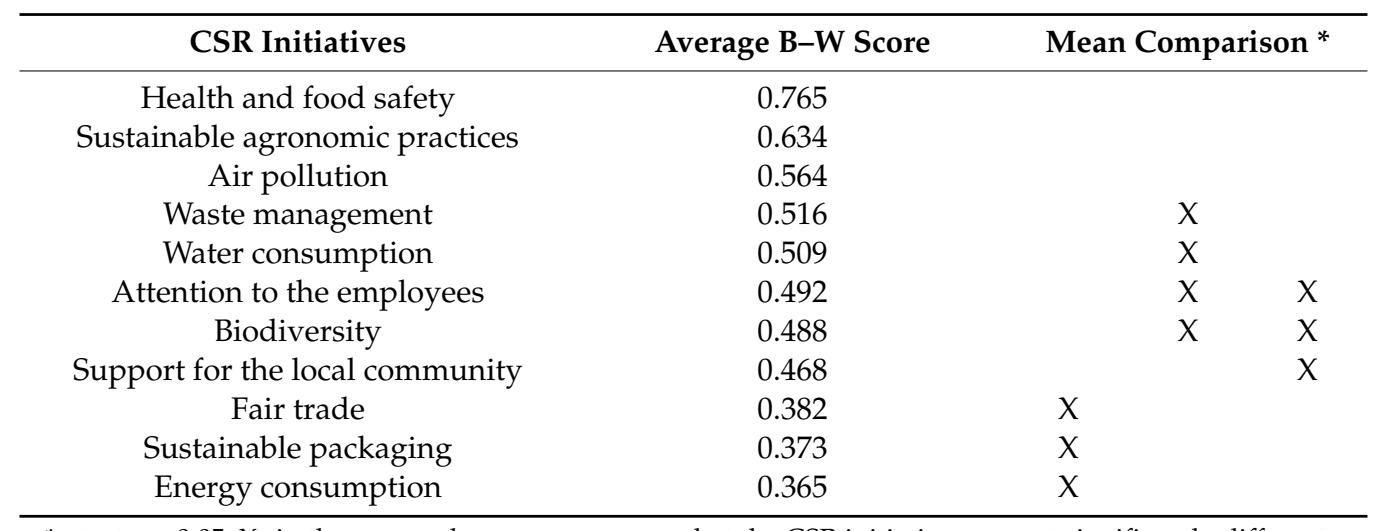

${ }^{*} \mathrm{t}$-test $p<0.05 ; \mathrm{Xs}$ in the same column or row mean that the CSR initiatives are not significantly different. 


\subsection{CSR Information Conveyed by the Four Wine Certifications}

The second aim posed by the study was to uncover the CSR information conveyed by the four wine certifications. As shown in Figure 1, all the wine certifications investigated, although differently, are able to cover the entire domains of CSR.

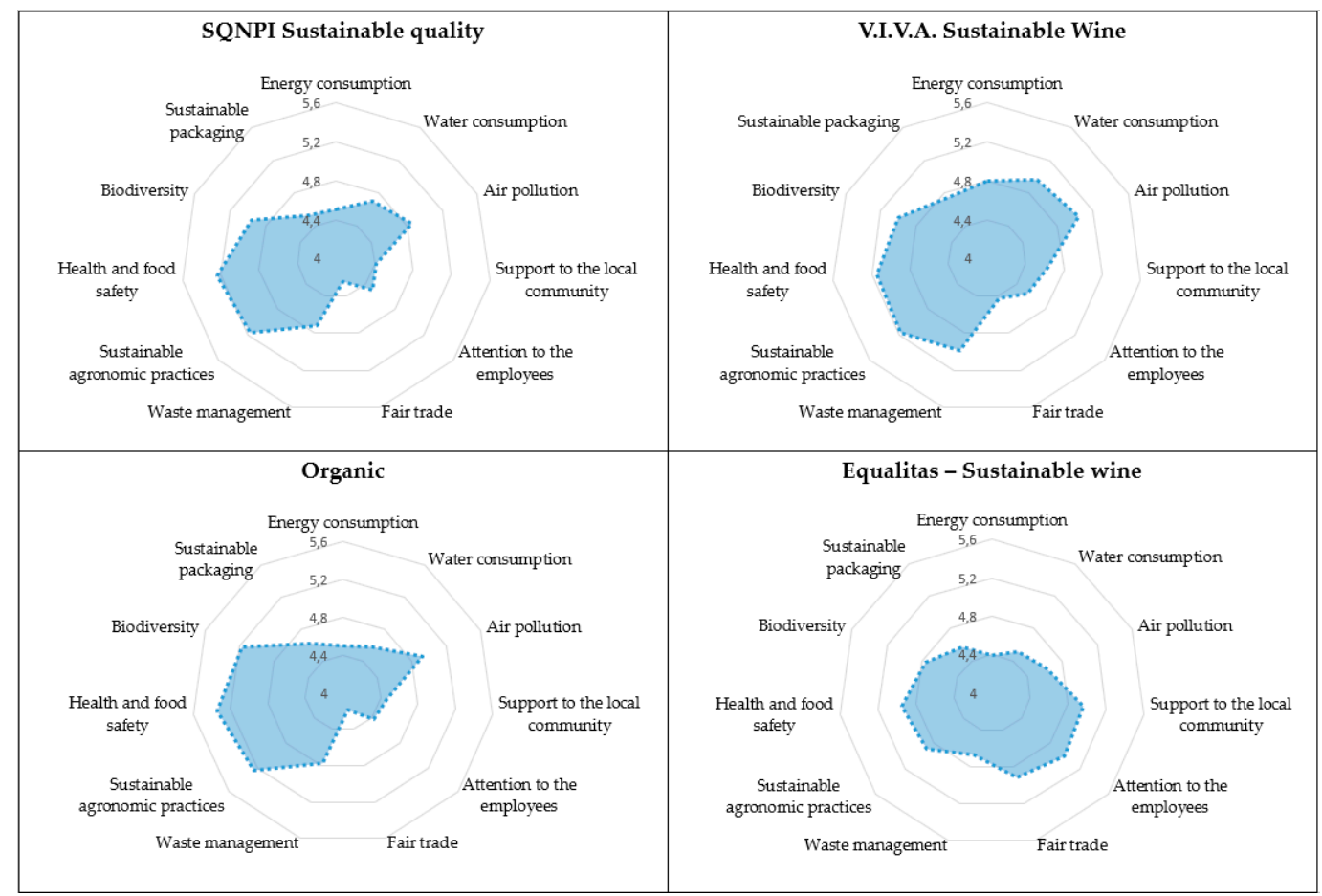

Figure 1. Consumers' perception of the wine certifications for the 11 CSR initiatives.

Further, Organic, SQNPI Sustainable Quality, and V.I.V.A. Sustainable Wine certifications are perceived similarly by consumers in terms of few CSR initiatives. Indeed, they are positively perceived by consumers in terms of "health and food safety" and "sustainable agronomic practices" CSR initiatives. The latter along with "biodiversity" received higher scores in the Organic certification compared to the others. Consumers also consider Organic wine attentive to "air pollution" while less involved in supporting the economic development of the territory (i.e., "fair trade"). Consumers attach a similar valuation to SQNPI Sustainable Quality certification. V.I.V.A. Sustainable Wine performs well in such CSR initiatives as "air pollution", "biodiversity", and "water consumption". Lastly, Equalitas-Sustainable Wine is mostly associated with the social dimension of CSR. Consumers, in fact, assign to this certification a higher commitment to "support for the local community", "attention to the employees", and "fair trade".

\subsection{Consumers' price premium for the Wine Certifications}

Uncovering the price premium consumers are willing to pay for wines produced by wineries implementing CSR was the third aim addressed in the study. The study, for each of the four certifications investigated, asked participants to state how much they were willing to pay for a $750 \mathrm{~mL}$ bottle of certified red wine, compared to another without certification. Respondents expressed their price premium on a scale ranging from $€ 0.00$ to $€ 3.00$ with increments of 50 euro cents. Table 8 shows descriptive statistics of consumers' price premium for the four certified wines investigated. 
Table 8. Consumers' price premium for the four certified wines $(€)$.

\begin{tabular}{lcccc}
\hline \multicolumn{1}{c}{ Certification } & Mean & SD & Min & Max \\
\hline SQNPI Sustainable Quality & 1.29 & 0.94 & 0.00 & 3.00 \\
V.I.V.A. Sustainable Wine & 1.53 & 0.86 & 0.00 & 3.00 \\
Organic & 1.66 & 0.93 & 0.00 & 3.00 \\
Equalitas-Sustainable Wine & 1.37 & 0.89 & 0.00 & 3.00 \\
\hline
\end{tabular}

Results shows that consumers assigned the highest price premium to the Organic wine (Mean: $€ 1.66)$, while the lowest one to the SQNPI Sustainable Quality certification (€1.29). As for the highest price level expressed by respondents, the study suggests that $19 \%$ of consumers are willing to pay a price premium of $€ 3.00$ for Organic wine compared to the V.I.V.A. Sustainable Wine, SQNPI Sustainable Quality, and Equalitas-Sustainable Wine (14\%, 13\%, and 11\% of the sample, respectively) (Figure 2).

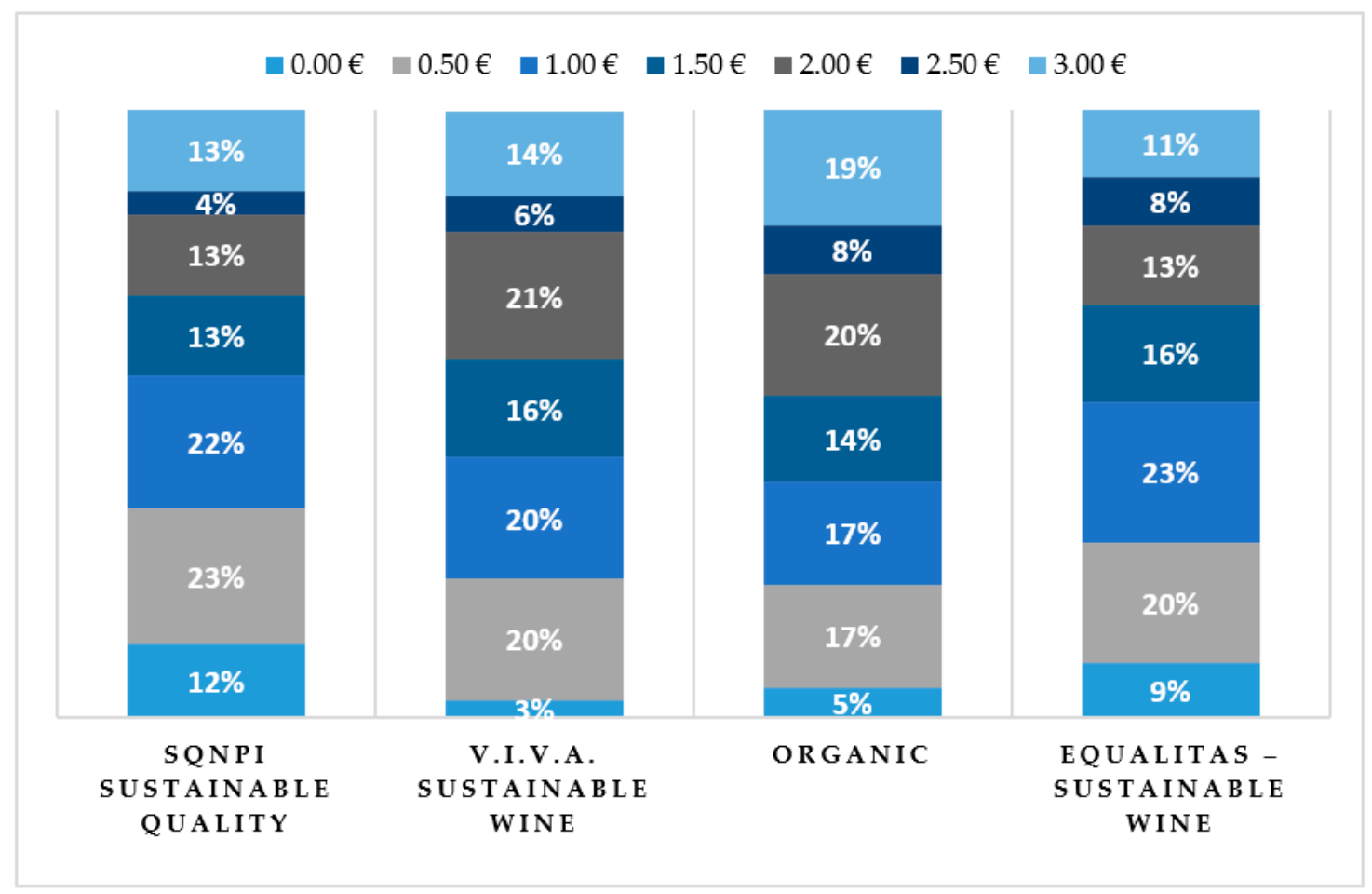

Figure 2. Consumers' price premium by price range $(€)$ for the four certified wines.

\section{Discussion}

This study aimed to overcome some the limitations occurring in previous studies $[39,49]$, investigating consumers' preferences for as many as 11 CSR initiatives implemented in the wine sector. Prior studies, in fact, focused mostly on a few CSR activities such as the environmental one, neglecting those related to the ethical and social aspects. The current study also attempted to investigate how consumers perceive the CSR efforts conveyed by the main Italian wine certifications related to CSR, as well as their price premium for the certified wines. Acquiring knowledge about the CSR initiatives consumers are willing to pay more would enable wineries to rethink their business strategies. Further, they will better serve their consumers, delivering on the market a product that meets their preferences.

The study showed that food healthiness and safety is relevant for consumers. Previous scholars pointed out that this aspect is decisive in affecting consumers' purchasing decisions and WTP for food products $[23,35,57]$. This interest may be due to the several food scandals that have undermined consumers' trust in the food sector $[20,58]$. Study participants ranked "sustainable agricultural practices" as the second most important CSR initiative that wineries should focus on. The food sector is 
often under scrutiny for environmental issues arising from the conventional agricultural practices that massively rely on the use of pesticides and fertilizers [58]. As for consumers' preferences regarding such CSR initiatives as "air pollution" and "waste management", previous studies revealed contrasting results. A similar study on consumers' preferences towards CSR in the dairy sector [24,30,31] showed that consumers are less interested in these CSR initiatives. However, this may also depend by the sector investigated. For instance, some food sectors may have a larger effect on some CSR dimensions that in turn raise consumers' awareness. "Water consumption" emerged among those positively evaluated by consumers. This result is in contrast with the one of Pomarici et al. [59] who found a limited interest in wine with a reduced water footprint. To this extent, the attention towards the use of water resources may be affected by respondents' age. Indeed, while older consumers still show limited concern for water saving, mainly due to a lack of knowledge on water footprint, younger consumers are more informed and concerned about sustainability and the exploitation of natural resources [60].

Overall, consumers expressed a positive perception in terms of CSR performance for all the certifications investigated, while their price premium was higher for the Organic one. This is consistent with the best-worst scaling results. Indeed, respondents ranked "health and food safety" and "sustainable agricultural practices" as the most important CSR initiatives. Organic certification was also assessed as high in these two areas. The high price premium uncovered for this certification may be related to its diffusion in the market, as well as the consolidated knowledge of consumers towards this certification [61]. Although the main focus of the Organic certification is on reducing the environmental impact [41], previous studies showed that it is often associated with many CSR dimensions [61], such as food safety [62], healthy food [63], environmental protection [64], and ethical and social issues [65]. The lower price premium observed for the other certifications investigated may be due to their recent launch on the market and the limited focus on the wine. Accordingly, consumers may be not aware of the certification protocols and CSR initiatives accounted for.

\section{Study Implications and Limitations}

The results of the study offer useful implications for wineries. Since "health and food safety" and "sustainable agronomic practices" are the CSR initiatives most preferred by consumers and particularly associated with Organic certification, wineries may decide to invest more in this certification. This will allow producers to strengthen their turnover by selling their wines at a higher price. Despite their lower value, consumers expressed positive perception and price premium for the other certifications investigated as well. However, albeit with small differences, consumers perceived the four wine certifications almost indistinctly. Accordingly, wineries who decide to invest in these certifications should address their efforts on communication to better convey their peculiarities mainly in terms of CSR initiatives accounted for.

The study has some limitations that limit generalization of results. First of all, the study findings may not represent the preferences of wine consumers in Italy. This limitation is due to the limited number of participants in the study and the sampling method implemented. Accordingly, future research may involve a larger sample to increase the representativeness of the study results. Future studies may also segment the sample on the basis of participants' socio-demographic characteristics and consumption habits to identify potential changes in consumers' preferences for the CSR initiatives investigated. Scholars may also extend the analysis to other wine certifications related to corporate social responsibility. A further limitation concerns the methodology implemented to detect consumers' price premium. Furthermore, the study findings rely on stated preferences and not on revealed preferences. Thus, the price premium assessed may be overestimated by consumers due to potential hypothetical and social desirability bias. Finally, a limited amount of information was provided to consumers about the CSR initiatives investigated, and this may have affected the results of the B-W analysis.

Author Contributions: 1. Introduction, 4. Discussion, 5. Study implications and limitations, M.L.; 2. Materials and methods and 3. Results, M.S. All authors have read and approved the final manuscript. 
Funding: This research received no external funding.

Conflicts of Interest: The authors declare no conflict of interest.

\section{References}

1. Bigliardi, B.; Galati, F. Innovation trends in the food industry: the case of functional foods. Trends Food Sci. Tech. 2013, 31, 118-129. [CrossRef]

2. Giacosa, E.; Giachino, C.; Bertoldi, B.; Stupino, M. Innovativeness of Ceretto Aziende Vitivinicole: A First Investigation into a Wine Company. Int. Food Agribus. Man. 2014, 17, $223-236$.

3. Di Vita, G.; Chinnici, G.; Pappalardo, G.; D’Amico, M.; Bracco, S. Standard output versus standard gross margin, a new paradigm in the EU farm economic typology: what are the implications for wine-grape growers? J. Wine Res. 2014, 25, 229-242. [CrossRef]

4. Rapporto 2019 ISMEA-Qualivita sulle produzioni agroalimentari e vitivinicole italiane DOP, IGP e STG. Available online: http://www.ismea.it/flex/cm/pages/ServeAttachment.php/L/IT/D/d\%252F1\%252Fc\%252FD. 5dc105037cf9be92b910/P/BLOB\%3AID\%3D10971/E/pdf (accessed on 22 June 2020).

5. Corsi, A.; Mazzarino, S.; Pomarici, E. The Italian Wine Industry. In The Palgrave Handbook of Wine Industry Economics; Palgrave Macmillan: Cham, Switzerland, 2019; pp. 47-76.

6. Santoro, A.; Venturi, M.; Agnoletti, M. Agricultural Heritage Systems and Landscape Perception among Tourists. The Case of Lamole, Chianti (Italy). Sustainability 2020, 12, 3509. [CrossRef]

7. Asero, V.; Patti, S. From wine production to wine tourism experience: the case of Italy. Available online: https://www.researchgate.net/publication/46471640_From_Wine_Production_to_Wine_Tourism_ Experience_The_Case_of_Italy (accessed on 22 June 2020).

8. Stanco, M.; Lerro, M.; Marotta, G. Consumers' Preferences for Wine Attributes: A best-worst Scaling Analysis. Sustainability 2020, 12, 2819. [CrossRef]

9. Wongprawmas, R.; Spadoni, R. Is innovation needed in the Old World wine market? The perception of Italian stakeholders. Br. Food J. 2018, 120, 1315-1329. [CrossRef]

10. Pomarici, E.; Lerro, M.; Chrysochou, P.; Vecchio, R.; Krystallis, A. One size does (obviously not) fit all: Using product attributes for wine market segmentation. Wine Econ. Policy 2017, 6, 98-106. [CrossRef]

11. Sogari, G.; Mora, C.; Menozzi, D. Factors driving sustainable choice: The case of wine. Br. Food J. 2016, 118, 632-646. [CrossRef]

12. Sajdakowska, M.; Jankowski, P.; Gutkowska, K.; Guzek, D.; Żakowska-Biemans, S.; Ozimek, I. Consumer acceptance of innovations in food: A survey among Polish consumers. J. Consum. Behav. 2018, 17, 253-267. [CrossRef]

13. Pomarici, E.; Vecchio, R. Millennial generation attitudes to sustainable wine: An exploratory study on Italian consumers. J. Clean. Prod. 2014, 66, 537-545. [CrossRef]

14. Vecchio, R.; Lisanti, M.T.; Caracciolo, F.; Cembalo, L.; Gambuti, A.; Moio, L.; Siani, T.; Marotta, G.; Nazzaro, C.; Piombino, P. The role of production process and information on quality expectations and perceptions of sparkling wines. J. Sci. Food Agric. 2019, 99, 124-135. [CrossRef] [PubMed]

15. Marotta, G.; Nazzaro, C. Public goods production and value creation in wineries: a structural equation modelling. Br. Food J. 2020, 122, 1705-1724. [CrossRef]

16. Lerro, M.; Vecchio, R.; Nazzaro, C.; Pomarici, E. The growing (good) bubbles: Insights into US consumers of sparkling wine. Br. Food J. 2019. [CrossRef]

17. Nazzaro, C.; Marotta, G.; Rivetti, F. Responsible innovation in the wine sector: A distinctive value strategy. Agric. Agric. Sci. 2016, 8, 509-515. [CrossRef]

18. Sica, D.; Malandrino, O.; Esposito, B.; Supino, S.; Sessa, M.R. The Pathway towards Social Responsibility in Italian Wine Sector: The Feudi di San Gregorio SpA Experience. J. Health Sci. 2019, 7, 273-281.

19. Lerro, M.; Vecchio, R.; Caracciolo, F.; Pascucci, S.; Cembalo, L. Consumers' heterogeneous preferences for corporate social responsibility in the food industry. Corp. Soc. Resp. Env. Ma. 2018, 25, 1050-1061. [CrossRef]

20. Marotta, G.; Nazzaro, C. Responsabilità Sociale e Creazione di Valore Nell'impresa Agroalimentare: Nuove Frontiere Di Ricerca. Econ. Agro-Alimentare 2012, 42, 13-54. [CrossRef]

21. Pirsch, J.; Gupta, S.; Grau, L.S. An Exploratory Study Framework for Understanding Programs Corporte Social Responsibility as a Continuum: An Exploratory Study. J. Bus. Ethics 2012, 70, 125-140. [CrossRef] 
22. Lerro, M.; Raimondo, M.; Stanco, M.; Nazzaro, C.; Marotta, G. Cause Related Marketing among Millennial Consumers: The Role of Trust and Loyalty in the Food Industry. Sustainability 2019, 11, 535. [CrossRef]

23. Nazzaro, C.; Stanco, M.; Marotta, G. The Life Cycle of Corporate Social Responsibility in Agri-Food: Value Creation Models. Sustainaility 2020, 12, 1287. [CrossRef]

24. Deselnicu, O.; Costanigro, M.; Thilmany, D.D. Corporate social responsibility initiatives and consumer preferences in the dairy industry. Available online: https://econpapers.repec.org/paper/agsaaea12/124616.htm (accessed on 22 June 2020).

25. Marotta, G.; Nazzaro, C.; Stanco, M. How the social responsibility creates value: Models of innovation in Italian pasta industry. IJGSB 2017, 9, 144-167. [CrossRef]

26. Boccia, F.; Sarnacchiaro, P. The impact of corporate social responsibility on consumer preference: A structural equation analysis. Corp. Soc. Resp. Env. Ma. 2018, 25, 151-163. [CrossRef]

27. Arcese, G.; Lucchetti, M.C.; Massa, I. Modeling social life cycle assessment framework for the Italian wine sector. J. Clean. Prod. 2017, 140, 1027-1036. [CrossRef]

28. Mueller, H.; Theuvsen, L. Influences on consumer attitudes towards CSR in agribusiness. Available online: https://ageconsearch.umn.edu/record/166108/ (accessed on 22 June 2020).

29. Morgan, C.J.; Widmar, N.J.O.; Wilcoxc, M.D.; Croney, C.C. Perceptions of agriculture and food corporate social responsibility. J. Food Prod. Market 2018, 24, 146-162. [CrossRef]

30. McFadden, D.T.; Deselnicu, O.; Costanigro, M. How Consumers Respond to Corporate Social Responsibility Initiatives: A Cluster Analysis of Dairy Consumers. J. Food Distrib. Res. 2013, 44, 17-24.

31. Costanigro, M.; Deselnicu, O.; McFadden, D.T. Product differentiation via corporate social responsibility: consumer priorities and the mediating role of food labels. Agr. Hum. Values 2016, 33, 597-609. [CrossRef]

32. Luhmann, H.; Theuvsen, L. CSR activities in the German poultry sector: differencing preference groups. Int. Food Agribus. Man. 2016, 20, 321-334. [CrossRef]

33. Del Giudice, T.; Stranieri, S.; Caracciolo, F.; Ricci, E.C.; Cembalo, L.; Banterle, A.; Cicia, G. Corporate Social Responsibility certifications influence consumer preferences and seafood market price. J. Clean. Prod. 2018, 178, 526-533. [CrossRef]

34. Schäufele, I.; Hamm, U. Consumers' perceptions, preferences and willingness-to-pay for wine with sustainability characteristics: A review. J. Clean. Prod. 2017, 147, 379-394. [CrossRef]

35. Forbes, S.L.; Cohen, D.A.; Cullen, R.; Wratten, S.D.; Fountain, J. Consumer attitudes regarding environmentally sustainable wine: an exploratory study of the New Zealand marketplace. J. Clean. Prod. 2009, 17, 1195-1199. [CrossRef]

36. D'Amico, M.; Di Vita, G.; Monaco, L. Exploring environmental consciousness and consumer preferences for organic wines without sulfites. J. Clean. Prod. 2016, 120, 64-71. [CrossRef]

37. Tait, P.; Saunders, C.; Dalziel, P.; Rutherford, P.; Driver, T.; Guenther, M. Estimating wine consumer preferences for sustainability attributes: A discrete choice experiment of Californian Sauvignon blanc purchasers. J. Clean. Prod. 2019, 233, 412-420. [CrossRef]

38. Sellers-Rubio, R. Would you Pay a Price Premium for a Sustainable Wine? The Voice of the Spanish Consumer. Agric. Agric. Sci. Procedia 2016, 8, 10-16.

39. Vecchio, R. Determinants of willingness-to-pay for sustainable wine: Evidence from experimental auctions. Wine Econ. Policy 2013, 2, 85-92. [CrossRef]

40. Gassler, B. How green is your 'Grüner'? Millennial wine consumers' preferences and willingness-to-pay for eco-labeled wine. Jahrbuch der Österreichischen Gesellschaft für Agrarökonomie 2015, 24, 131-140.

41. Corbo, C.; Lamastra, L.; Capri, E. From environmental to sustainability programs: a review of sustainability initiatives in the Italian wine sector. Sustainability 2014, 6, 2133-2159. [CrossRef]

42. Szolnoki, G. A cross-national comparison of sustainability in the wine industry. J. Clean. Prod. 2013, 53, 243-251. [CrossRef]

43. Bastianoni, S.; Marchettini, N.; Panzieri, M.; Tiezzi, E. Sustainability assessment of a farm in the Chianti area (Italy). J. Clean. Prod. 2001, 9, 365-373. [CrossRef]

44. Marchettini, N.; Panzieri, M.; Niccolucci, V.; Bastianoni, S.; Borsa, S. Sustainability indicators for environmental performance and sustainability assessment of the production of four Italian wines. Int. J. Sust. Dev. World 2003, 10, 275-282. [CrossRef] 
45. Bosco, S.; di Bene, C.; Galli, M.; Remorini, D.; Massa, R.; Bonari, E. Greenhouse gas emissions in the agricultural phase of wine production in the Maremma rural district in Tuscany, Italy. Ital. J. Agron. 2011, 6, 93-100. [CrossRef]

46. Vazquez-Rowe, I.; Rugani, B.; Benetto, E. Tapping carbon footprint variations in the European wine sector. J. Clean. Prod. 2013, 43, 146-155. [CrossRef]

47. Ardente, F.; Beccali, G.; Cellura, M.; Marvuglia, A. POEMS: A Case Study of an Italian Wine-Producing Firm. Environ. Manag. 2006, 38, 350-364. [CrossRef] [PubMed]

48. Pomarici, E.; Vecchio, R.; Verneau, F. A future of sustainable wine? A reasoned review and discussion of ongoing programs around the world. Calitatea 2014, 15, 123-128.

49. Sogari, G.; Corbo, C.; Macconi, M.; Menozzi, D.; Mora, C. Consumer attitude towards sustainable-labelled wine: An exploratory approach. Int. J. Wine Bus. Res. 2015, 27, 312-328. [CrossRef]

50. Cohen, E. Applying best-worst scaling to wine marketing. IJWBR 2009, 21, 8-23. [CrossRef]

51. Finn, A.; Louviere, J.J. Determining the Appropriate Response to Evidence of Public Concern: The Case of Food Safety. J. Public Policy Mark. 1992, 11, 12-25. [CrossRef]

52. Auger, P.; DeVinney, T.M.; Louviere, J. Using Best-Worst Scaling Methodology to Investigate Consumer Ethical Beliefs Across Countries. J. Bus. Ethics 2006, 70, 299-326. [CrossRef]

53. Burke, P.; Eckert, C.; Davis, S. Segmenting consumers' reasons for and against ethical consumption. Eur. J. Mark. 2014, 48, 2237-2261. [CrossRef]

54. Lerro, M.; Marotta, G.; Nazzaro, C. Measuring consumers' preferences for craft beer attributes through best-worst Scaling. AFE 2020, 8, 1-13.

55. Lusk, G. Food values. Science 1917, 45, 345-350. [CrossRef]

56. Goodman, S.; Lockshin, L.; Cohen, E.; Fensterseifer, J.; Ma, H.; d'Hauteville, F.; Jaeger, S. International comparison of consumer choice for wine: A twelve country comparison. In Proceedings of the 4th international conference of the academy of wine business research, Siena, Italy, 17-19 July 2008.

57. Brugarolas Molla-Bauza, M.; Martinez-Carrasco Martinez, L.; Martinez Poveda, A.; Rico Perez, M. Determination of the surplus that consumers are willing to pay for an organic wine. Span. J. Agric. Res. 2005, 3, 43-51.

58. Lyons, K.; Burch, D.; Lawrence, G.; Lockie, S. Contrasting paths of corporate greening in Antipodean agriculture: organics and green production. Jansen, K., Vellema, S., Eds.; In Agribusiness and Society: Corporate Responses to Environmentalism, Market Opportunities and Public Regulation; Zed Books: New York, NY, USA, 2004.

59. Pomarici, E.; Amato, M.; Vecchio, R. Environmental friendly wines: a consumer segmentation study. Agric. Agric. Sci. Procedia 2016, 8, 534-541. [CrossRef]

60. Sogari, G.; Pucci, T.; Aquilani, B.; Zanni, L. Millennial generation and environmental sustainability: The role of social media in the consumer purchasing behavior for wine. Sustainability 2017, 9, 1911. [CrossRef]

61. Loose, S.M.; Remaud, H. Impact of corporate social responsibility claims on consumer food choice: A cross-cultural comparison. Br. Food J. 2013, 115, 142-166. [CrossRef]

62. Harper, G.C.; Makatouni, A. Consumer perception of organic food production and farm animal welfare. $\mathrm{Br}$. Food J. 2002, 104, 287-299.

63. Bech-Larsen, T.; Grunert, K.G. The perceived healthiness of functional foods: a conjoint study of Danish, Finnish and American consumers' perception of functional foods. Appetite 2003, 40, 9-14. [CrossRef]

64. Magnusson, M.K.; Arvola, A.; Hursti, U.K.K.; Åberg, L.; Sjödén, P.O. Choice of organic foods is related to perceived consequences for human health and to environmentally friendly behaviour. Appetite 2003, 40, 109-117. [CrossRef]

65. Briggeman, B.C.; Lusk, J.L. Preferences for fairness and equity in the food system. Eur. Rev. Agric. 2011, 38, 1-29. [CrossRef]

(C) 2020 by the authors. Licensee MDPI, Basel, Switzerland. This article is an open access article distributed under the terms and conditions of the Creative Commons Attribution (CC BY) license (http://creativecommons.org/licenses/by/4.0/). 